\title{
The Living Conditions of Children
}

\author{
Harry Anthony Patrinos*
}

\begin{abstract}
This paper summarizes the socioeconomic conditions of children around the world. It explores solutions to the main problems, along with a summary of the costs and benefits of some of the solutions. Emphasis is on the results from rigorous studies, impact evaluations and randomized experiments. Although the cost-evidence literature is scarce, a good case for early interventions and key quality-enhancing education interventions exists.
\end{abstract}

JEL Codes: J13; I21

Keywords: children, early childhood interventions, education

World Bank Policy Research Working Paper 4251, June 2007

The Policy Research Working Paper Series disseminates the findings of work in progress to encourage the exchange of ideas about development issues. An objective of the series is to get the findings out quickly, even if the presentations are less than fully polished. The papers carry the names of the authors and should be cited accordingly. The findings, interpretations, and conclusions expressed in this paper are entirely those of the authors. They do not necessarily represent the view of the World Bank, its Executive Directors, or the countries they represent. Policy Research Working Papers are available online at http://econ.worldbank.org.

\footnotetext{
*hpatrinos@worldbank.org. Paper commissioned by the Copenhagen Consensus. The assistance received from Husein Abdul-Hamid and Vicente Garcia-Moreno is gratefully appreciated.
} 
This paper summarizes the socioeconomic conditions of children around the world. It is part of a larger effort to take stock of the world's biggest problems and the most promising solutions, and to provide informed input into the policy-making process surrounding efforts to deal with these problems. ${ }^{1}$ The aim is to provide an in-depth assessment of the costs and benefits of solutions to some of the problems facing children today. Emphasis is on the results from rigorous studies, impact evaluations and randomized experiments. Although the cost-evidence literature is scarce, a good case for early interventions and key quality-enhancing education interventions exists.

\section{Extent of the problem}

Nearly half the people of the world today are under 25 years of age. Nine out of ten of these young people live in developing countries. More importantly, the majority of the developing world's poor is children and youth, defined either as being under the age of 18 years (based on the 1989 United Nations Convention on the Rights of the Child) or up to 14 years (based on the Millennium Development Goal (MDG) framework). Although significant progress has been made in reducing poverty worldwide, the fact remains that most of the MDG outcomes are not likely to be met unless greater attention is paid to the next generation (World Bank 2005). Children are the hardest hit by poverty. More than half a billion children (40 percent of all) in developing countries are living on less than $\$ 1$ a day (UNICEF 2005).

There are 115 million primary-school-aged children not enrolled in school (UNESCO 2005). Another 150 million children start primary school but drop out before they have completed four years of education. Nearly half of the children in the least developed countries of the world do not have access to primary education. Of the 115 million primary school-aged children out of school, the majority are in Sub-Saharan Africa and South Asia (76 percent). More than 45 percent of children in west and central Africa are out of school. More than 42 million children in South Asia are out of school.

For every 100 boys out of school, 117 girls miss out on primary education. While the gender gap in primary education has been closing steadily, many countries have failed to meet

\footnotetext{
${ }^{1}$ The Copenhagen Consensus 2008 is the follow-up to the successful Copenhagen Consensus 2004. Funded by the Danish Ministry of Foreign Affairs, it will take stock of the world's biggest problems and the most promising solutions and provide informed input into the policy making process surrounding efforts to deal with these problems.
} 
the MDG target of gender parity in primary education by 2005, and the regions with the highest gaps will have to make even greater gains if gender parity is to be achieved as part of universal primary school completion by 2015. Girls' exclusion from education in comparison to boys, especially in South Asia, Sub-Saharan Africa and the Middle East and North Africa, is one of the clearest indicators of gender discrimination (UNICEF 2005).

Of those children in developing countries that are in school, most are not learning adequately. The few participating countries in international achievement tests such as TIMSS, PIRLS and PISA usually score near the bottom, especially when compared to middle and highincome countries. Their levels of comprehension are minimal in important subjects such as math, science and reading. In fact, 54 percent of Peruvian 15-year-olds are at the lowest level of comprehension in reading according to the OECD's PISA assessment; while 23 percent of youth in Argentina and Brazil, 31 percent in Indonesia, and 10 percent in Thailand are at this level. By contrast only 3 and 4 percent of youth in the United Kingdom and France score at this level.

Although life expectancy has increased, 10 million children die every year before their fifth birthday (UNICEF 2005), largely from preventable causes, and malnutrition is a contributing factor in more than half of these. More than 50 percent of the 10 million children die at home due to poor access to health care. Acute respiratory infections are the biggest single killer (2 million every year), followed by diarrhoeal diseases, malaria, measles, pertussis, tuberculosis and neonatal tetanus. More than half a million children die of HIV/AIDS each year. Maternal mortality ratios have remained high in some parts of the world, at 1,100 deaths per 100,000 live births in Sub-Saharan Africa and 440 in developing countries, compared to 12 for developed countries (Belli and Appaix 2003).

More than half the world's children still have no access to safe water and sanitation (UNICEF 2002). While an estimated 1 billion people gained access to improved drinking water sources in the 1990s and global coverage rose from 77 to 82 percent, some 1.1 billion people, mostly from the poorest countries, still lack access to safe water. Gains were registered in increasing access to sanitary facilities yet a staggering 2.4 billion people still lack such access. Four out of five of them are found in Asia. Lack of access to safe drinking water or inadequate 
hygiene and sanitation cause over 3 million child deaths a year in developing countries - about one in every four such deaths. Moreover, fetching water is a time-consuming activity that is shouldered almost exclusively by women and children (UNICEF 2000).

Violent conflicts, along with HIV/AIDS, are giving rise to a massive generation of orphans in Sub-Saharan Africa. The region has 13 million orphans, most under the age of 15. In many countries, children and adolescents take part as soldiers. More than 300,000 children under 18 are fighting in armed conflicts in more than 30 countries worldwide. Over 300 million young people below the age of 25 live in countries affected by armed conflict (Rahim and Holland 2006). There are 26 countries in the world with at least a quarter of a million internally displaced persons and 15 countries and territories with 250,000 refugees (Sommers 2002). Two million children died as a direct result of armed conflict over the last decade. Six million children were seriously injured or permanently disabled (World Bank 2005).

Child labor persists in developing countries. More than 250 million children between the ages of 5-14 work. Most working children in rural areas were found in agriculture; urban children worked in trade and services, with fewer in manufacturing, construction and domestic service. Great efforts have been made to reduce this problem, with some positive results. Hageman et al. (2006) show that while 23 percent of children ages 5 to 17 worked in 2000, only 20 percent did in 2004. Estimates show that 11 percent of children worked in hazardous jobs in 2000 , while only 8 percent did so in 2004 , a 26 percent decrease.

Many inequalities within countries are obscured (UNICEF 2005). Indigenous peoples and ethnic minorities are at greatest risk. Over the period 1995-2004, the International Decade of the World's Indigenous Peoples, Latin America's indigenous peoples made rapid progress in political representation, health and education. However, indigenous peoples still account for the highest poverty rates in the region (Hall and Patrinos 2006). While Mexico will clearly achieve the MDGs on average, its large indigenous population - 10 percent of the total population or about 10 million people - is not making sufficient progress, but their experience is masked by the fact that data used to measure MDG progress is not disaggregated. 


\section{Solutions}

Although developing human capital is an easily agreed goal, finding cost-effective programs that lead to long-term increases is a challenge. Education represents both a human and social right for children everywhere, as well as a great investment. Monetary returns to schooling, through increased productivity and access to good jobs, and its contribution towards the elimination of poverty, make it a high priority investment everywhere. Despite the high proportions of resources allocated to education around the world, the challenge remains to find cost-effective ways to increase schooling among the poorest and to increase learning levels. There have been hundreds of empirical studies on the determinants of learning trying to estimate which factors affect school attainment and performance. Few have been based on randomized control experiments or used rigorous evaluation techniques. Nevertheless, there is little evidence to date that simply spending more money on schooling will improve outcomes. For example, in a review of almost 100 studies estimating the effects of resources on education outcomes, only 55 percent produced significant effects, and not all were positive (Hanushek 1995). Solutions to the education problem require, therefore, a closer look at rigorous, or randomized, evaluations.

Schooling clearly is a priority investment for children. There is a need to enroll all children in primary school, as well as pre-school. Getting children into school, and making sure that they complete their primary education, is effective for raising earnings in the future. Appropriate programs that address the supply and demand side can be very effective. Simply enforcing compulsory school legislation can be effective in raising school levels and increasing future earnings, as are programs designed to increase the supply of schooling, such as mass school construction programs; these findings have been verified by natural experiments. Duflo (2001) examines a large-scale school construction program in Indonesia by combining differences across regions in the number of schools constructed with differences across cohorts induced by the timing of the program. She shows that school construction led to overall increases in average schooling and wages. The returns to education range from 6-10 percent.

There is some evidence from India that spending, if well targeted, can improve outcomes. Banerjee et al. (2005) show evidence in favor of building new non-formal schools in unserved areas as a cheap way of expanding enrollment. Case and Deaton (1999) show that raising school 
resources increases years of completed schooling and enrollment rates for blacks, but not for whites, in South Africa. More evidence that spending can improve outcomes comes from the United States. Angrist and Guryan (2003) find that a \$1,000 increase in per-pupil spending leads to a $1 / 3$ to $1 / 2$ of a standard deviation increase in average test scores.

Various school inputs can be effective. Kremer et al. (2002) found that providing uniforms and textbooks and building classrooms for 7 schools randomly selected from a pool of 14 poorly performing schools led to a fall in dropout rates and after 5 years pupils in those schools had completed about 15 percent more years of schooling. In Chicago Jacob and Lefgren (2004) find a small, but statistically significant, positive effect of summer school and grade retention on student reading skills at a cost of about $\$ 750$ per student. This cost per student may be compared to other interventions, such as class size reduction, that have larger effects (more than three times as large) on student reading skills but cost more than $\$ 2,000$ per student.

Providing scholarships and other investments are among the most effective investments for increasing school enrollment and attendance. Schultz (2004) finds that Mexico's conditional cash transfer program, Oportunidades, increased the enrollment rate by 3.4 percent, on average. From Kenya, Kremer et al. (2004) show that introducing merit scholarships to study in secondary schools could provide access to further education for the best performing disadvantaged students. While universal free secondary education funded for all children would cost 18 percent of Kenya's GDP, targeting bright children with scholarships might lead to improvements in average academic performance. Angrist and Lavy (2002) find that cash awards raised test performance among 500 high school students in Israel. Various experiments have been undertaken to improve test scores in Kenyan schools. While scholarships for girls, teacher incentives and textbooks are significant, the most effective and cost-effective are the scholarships.

School-based programs can be very effective. Mexico's compensatory program provides extra resources to primary schools in disadvantaged rural communities. One of the most important components of the program is the school-based management intervention (AGEs). The impact assessment of the AGEs, controlling for the presence of the CCT program, shows a 
significant effect on the reduction of failure and grade repetition, at a yearly cost of $\$ 6$ per child (Gertler et al. 2006). Banerjee et al. (2004) conducted a randomized evaluation of a 2 year remedial education program in India. On average, the program increased test scores by 0.14 standard deviations in the first year and 0.28 in the second year, at a yearly cost of $\$ 5$ a child.

Schooling summary. Various attempts to improve schooling have been undertaken. The evidence on CCT-type programs and various incentives is strong and based on experimental data. Reducing demand-side constraints to school attendance and completion are a very costeffective intervention. They help put children in school, thus making other investments more productive. At the same time, more needs to be done to improve the quality of those schools once the children are enrolled. Improving quality will remain a challenge, but incentive programs and school-based management is proving to be a worthwhile investment.

Scientific and economic work shows the benefits of investing in children (Heckman 2006). The labor market improves as more able people acquire more skills, and more skilled people become more able (Heckman 2004; Carneiro and Heckman 2003). The main mechanism through which early education affects labor force productivity and crime is through its effect on cognitive and non-cognitive skills (Heckman and Masterov 2004). Early childhood interventions are more effective than remedies that attempt to compensate later in life. Enriched prekindergarten programs, with home visitation, have a strong track record of promoting achievement for disadvantaged children, improving labor market outcomes and reducing crime (Heckman 2004). Quality early education is a key part of the solution to this problem.

The Perry Preschool program started in 1962 with 123 young African-American children assessed to be at risk of school failure in Ypsilanti, Michigan, and is used to follow beneficiaries over four decades. The beneficiaries attended roughly two years of preschool for 2.5 hours/day, and received home visits from teacher once a week. Participants were compared to a control group that did not receive these services. Accumulated research shows significant returns (Barnett 2004; Currie and Thomas 1995). The greatest savings come from the reduction of crime and increases in earnings for participants (Barnett and Masse 2006). 
From the developing world significant benefits are found. Berlinski et al. (2006) exploit variation introduced by the expansion of a preschool program in Argentina to identify the impacts of the program on child outcomes. One year of pre-primary increases third grade test scores by 23 percent of the standard deviation of test score distribution. Armecin et al. (2006) evaluate an important early childhood initiative in the Philippines using longitudinal data collected over three years on a cohort of 6,693 children 0-4 years at baseline in two treatment regions and a control region. The authors find significant improvement in cognitive, social, motor and language development, and in short-term nutritional status.

Early interventions summary. Impact assessments of early interventions show significant short term benefits for the child, including enhanced achievement, improved health, increased non-cognitive skills, and social competence. In the medium term society benefits from greater school system efficiency; reduction in special education; reduction of grade repetition; higher learning; reduction in abuse and neglect; and lower reliance on public health care. In the long term, children benefit from higher likelihood of graduation and college enrollment; higher wages and employment; lower teen pregnancy; less delinquency. Society benefits from sound education; increased tax revenues; lower welfare dependence; and reduction in delinquency and crime.

Getting children into school early and compensating for disadvantage is important. However, due to poverty and other factors, many children continue to work, even combining school and work (Basu 1999; Psacharopoulos 1997; Psacharopoulos and Patrinos 1997; Rosati and Rossi 2003; Cigno et al. 2002). How to prevent child work is an ongoing challenge. Conditional cash transfer (CCT) programs aim to reduce current income poverty. They might affect child work through the cash transfers contingent on the child attending school regularly by reducing the opportunity cost of schooling. The CCT programs are not tied to the cessation of child work (PETI in Brazil is the exception). Oportunidades shows an overall reduction in work for male youth with no impacts on work for female youth. PETI reduces all child work by 8 percent. In Bangladesh, Ravallion and Wodon (2000) shows evidence of significant negative effect on the labor force participation of children through subsidies in school and nutrition. 
not measure the positive effects on children born to participant families after the study period (Temple and Reynolds 2006).

In Brazil, a benefit-cost ratio for preschool is 2 and the rate of return is $12-15$ percent. Most cost-benefit ratios for industrial and agricultural projects are less than 2 (World Bank 2001). In Egypt, focusing only on costs and benefits due only to increased enrollment in basic education and decreased repetition, a simulation shows a benefit-cost ratio of 2.3:1. Researches have estimated benefit-cost ratios of 2.4-3.2 for Bolivia (Van der Gaag and Tan 1998) and 3.0 for the Philippines (Glewwe et al. 2000; Table 2).

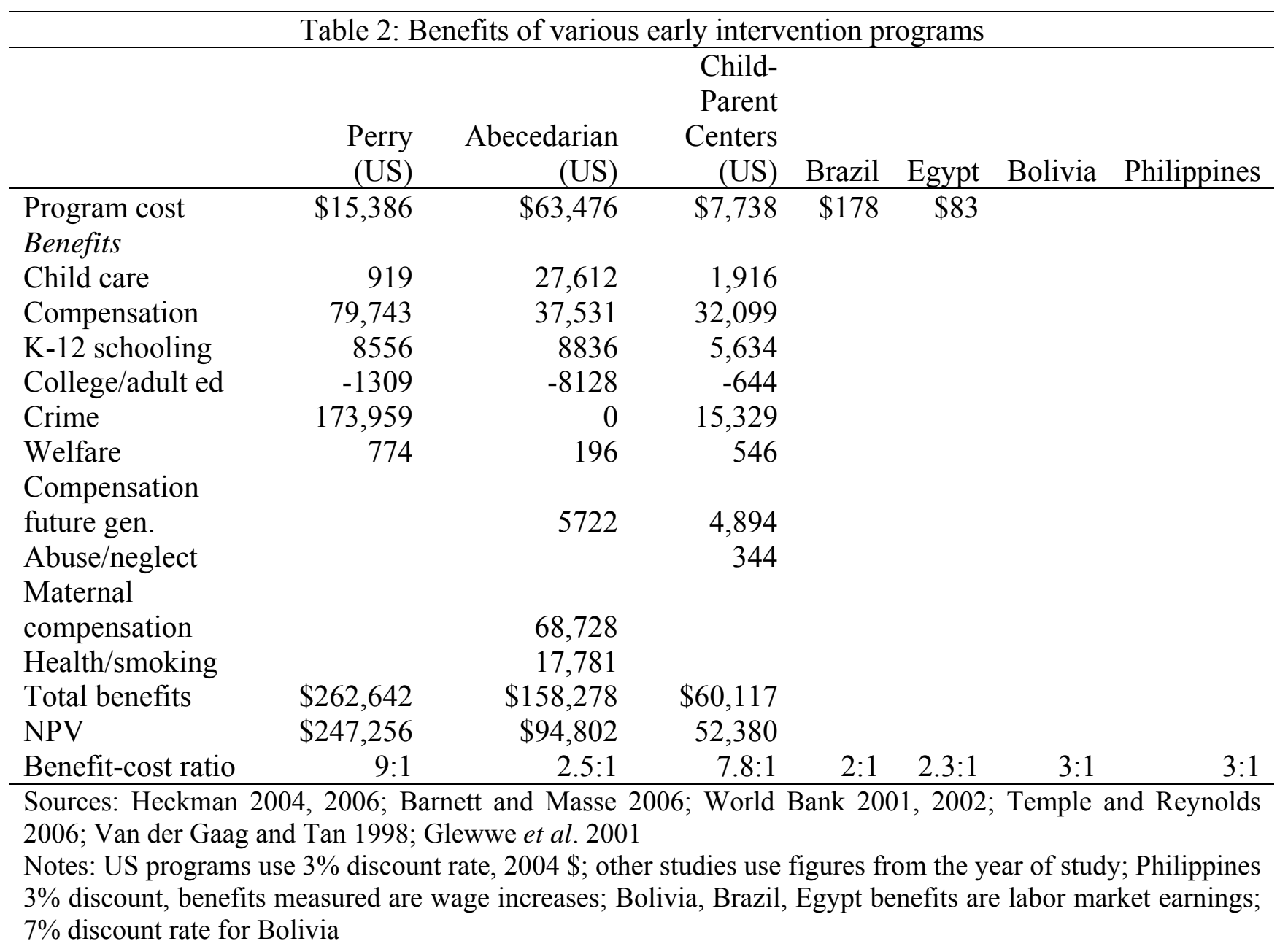

Evidence of cost effectiveness available for CCT comes from a study by Coady and Parker (2002), in which they compare the cost-effectiveness of cash transfer with the school 
building program, they show that in comparison with the building program, subsidies are around 11 times more cost effective in expanding enrollments.

The returns to schooling are high, and the savings associated with less schooling may be significant. The simulated costs (school supply, transfer, intervention, opportunity cost) and benefits (education and health) of eliminating child labor have been estimated, with a benefit to cost ratio of 5.4 (IPEC 2004). The question, however, is how to reduce child labor. CCT programs appear highly effective, given their short term goal of poverty alleviation and incentives to promote human capital development over the long run. The insistence on school enrollment helps to keep children enrolled, and rigorous evaluations have shown highly effective programs, especially on schooling, and on child labor reduction (Table 3). 
Table 3: Effectiveness of CCT programs

\begin{tabular}{|c|c|c|c|c|c|c|}
\hline $\begin{array}{l}\text { Program } \\
\text { (country) }\end{array}$ & $\begin{array}{c}\text { Type of } \\
\text { evaluation }\end{array}$ & Age & $\begin{array}{c}\text { School } \\
\text { enrollment } \\
\text { increase } \\
\text { (percentage } \\
\text { points) } \\
\end{array}$ & $\begin{array}{c}\text { Child work } \\
\text { reduction } \\
\text { (percentage } \\
\text { points) } \\
\text { Finding }\end{array}$ & $\begin{array}{l}\text { Stipend } \\
\text { (annual) }\end{array}$ & $\begin{array}{c}\text { Public } \\
\text { education } \\
\text { expenditure } \\
\text { (\% GDP } \\
\text { pc) }\end{array}$ \\
\hline $\begin{array}{l}\text { Red de } \\
\text { Protección } \\
\text { Social } \\
\text { (Nicaragua) }\end{array}$ & DID & $10-13$ & $18.0^{*}$ & $4.9^{*}$ & $\$ 21$ & 9.1 \\
\hline $\begin{array}{l}\text { Oportunidades } \\
\text { (Mexico) }\end{array}$ & Random & $\begin{array}{c}\text { 8-11 boys } \\
12-17 \text { boys } \\
8-11 \text { girls } \\
12-17 \text { girls }\end{array}$ & $\begin{array}{c}1.1-1.8^{*} \\
3.2-5.8^{*} \\
-- \\
7.5-9.5^{*}\end{array}$ & $\begin{array}{c}1.3 \\
3.2-4.7^{*} \\
-- \\
1.1-2.3^{*}\end{array}$ & $\begin{array}{l}\$ 109- \\
\$ 218\end{array}$ & 14.4 \\
\hline PETI (Brazil) & DID & $\begin{array}{c}10-14 \\
7-14\end{array}$ & $\begin{array}{l}- \\
--\end{array}$ & $\begin{array}{l}8.3^{*} \\
\text { N.S. }\end{array}$ & $\$ 173$ & 11.4 \\
\hline $\begin{array}{l}\text { Programa de } \\
\text { Asignación } \\
\text { Escolar } \\
\text { (Honduras) }\end{array}$ & & $6-12$ & -- & N.S. & $\$ 60$ & \\
\hline $\begin{array}{l}\text { Bangladesh's } \\
\text { Food for } \\
\text { Education }\end{array}$ & & $5-16$ & $16.0-17.0^{*}$ & $4.2^{*}$ & $\$ 35$ & 7.2 \\
\hline $\begin{array}{l}\text { Familias en } \\
\text { Acción } \\
\text { (Colombia) }\end{array}$ & DID & $\begin{array}{l}10-13 \text { rural } \\
14-17 \text { rural } \\
10-13 \text { urban } \\
14-17 \text { urban }\end{array}$ & $\begin{array}{l}1.5^{*} \\
5.0^{*} \\
7.0^{*} \\
2.5^{*}\end{array}$ & $\begin{array}{c}10.3-14.1^{* a} \\
\text { N.S. } \\
\text { Decrease } \\
\text { Decrease }\end{array}$ & $\begin{array}{l}\$ 96 \\
\$ 192\end{array}$ & 16.7 \\
\hline
\end{tabular}

Sources Raju 2005; Maluccio \& Flores 2004; Pianto \& Soares 2004; Attanasio \& others 2006a; Glewwe \& Olinto 2004

Note: Public expenditure data: Nicaragua 2004, Mexico 2004, Brazil 2000, Honduras, Bangladesh 2004, Colombia 2004

N.S. Not significant. ${ }^{a}=$ all ages

\section{Overview tables}

Our crude simulations of various options appear in Table 4. The lack of data in general, and more importantly the scarcity of rigorous, makes it difficult to go beyond the theoretical stage. Nevertheless, the evidence is sufficient to draw a few broad conclusions. Studies of the effects of pre-school education and other interventions on later performance have provided fairly conclusive evidence that quality early intervention programs can increase children's educational potential, and likely have long-lasting effects. Other interventions produce, in comparison, small benefits relative to cost. We present different scenarios to highlight these differences. These include improved school indicators: 5-16 percent reduction in grade repetition; 18-21 percent 
reduction in high school dropout rate; $14-26$ percent reduction in special education placement; higher grade completion rates in $2^{\text {nd }}, 3^{\text {rd }}$ and $4^{\text {th }}$ grades; higher scores on achievement tests; higher attendance; and less age-grade distortion. They include significant effects on economic potential: significantly higher monthly earnings; higher rates of home ownership; higher rates of school completion; and 18 percent chance of employment at age 19 (Filp 1983; Feijo 1984; Pontieri et al. 1981; Barnett 1995; Kagitcibasi et al. 1987). In order to make meaningful comparisons we build on this and use a Mincerian model for age-earning profile to make benefitcost scenarios. In all these scenarios the benefits are based on minimum estimates as there are many other side benefits that we did not attempt to estimate.

Scenario I: Preschool program. We look at an early childhood development intervention program that is based on pre-school education and use the above success indicators, and assuming the cost per child is $\$ 1,000$. Since the returns to schooling are different across countries and among countries, we looked at different levels (within the ranges in Psacharopoulos and Patrinos 2004): 5 percent return to a year of schooling in industrial countries, and 10 to 30 percent in very poor countries. We assume a discount rate of 10 percent.

Scenario II: Preschool plus nutrition and health. This scenario assumes the settings of scenario I and adds health and nutrition interventions before and during pre-school years. Benefit-cost calculations were conducted based on international studies of the effects of providing nutritional supplements and health interventions on survival, enrollment and achievement rates, and reducing dropout rates. We assume cost increases to $\$ 2,000$ a child.

Scenario III: Preschool, nutrition, health and classroom interventions in first two grades. This scenario assumes the settings of scenario II and adds more interventions (teacher training, additional material, breakfast, health). We assume a cost of $\$ 3,000$ a child.

In addition to these scenarios Table 4 includes similar benefit-cost calculations based on different comparable interventions. It is clear that the ECD interventions surpass other investments. A review of the literature suggests that early interventions are very cost-effective. Early interventions have the best payoff (Carneiro and Heckman 20054; Figure 1). 
Figure 1

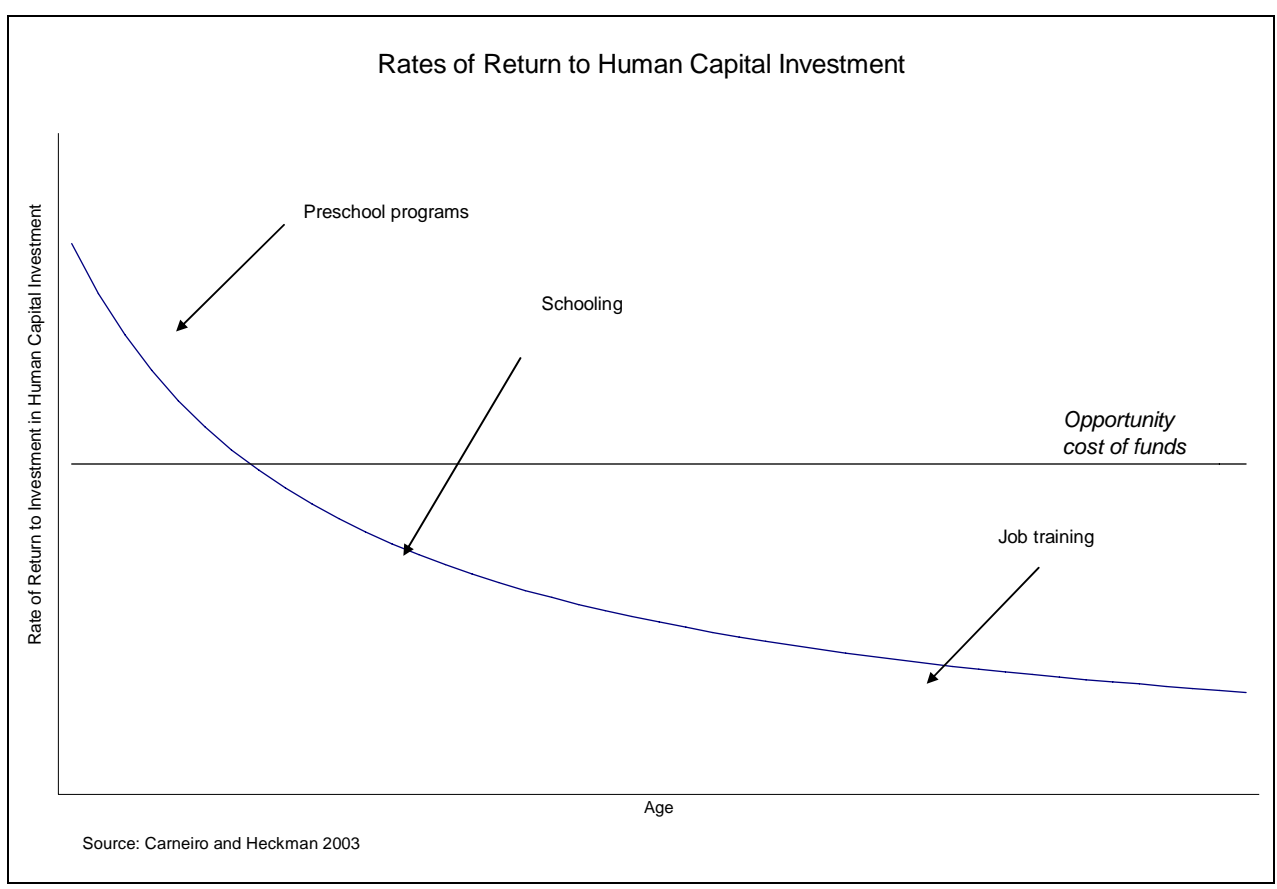


Table 4: Cost-Benefit Analysis of ECD Interventions in Comparison to Other Options

\begin{tabular}{|c|c|c|c|c|c|}
\hline \multirow[b]{3}{*}{ Rate of return to a year of schooling } & \multicolumn{5}{|c|}{ Economic status } \\
\hline & Poorest & $\begin{array}{l}\text { 2nd } \\
\text { level }\end{array}$ & Average & $\begin{array}{c}4 \text { th } \\
\text { level }\end{array}$ & Richest \\
\hline & 30 & 20 & 15 & 10 & 5 \\
\hline & \multicolumn{5}{|c|}{ Benefit/Cost ratio for intervention } \\
\hline $\begin{array}{l}\text { Scenario I: Early childhood development } \\
\text { program (focus on preschool) }\end{array}$ & 3.50 & 2.70 & 2.30 & 2.10 & 1.80 \\
\hline $\begin{array}{l}\text { Scenario II: Early childhood development } \\
\text { program (preschool plus nutrition and health } \\
\text { interventions) }\end{array}$ & 4.10 & 3.35 & 2.93 & 2.45 & 1.92 \\
\hline $\begin{array}{l}\text { Scenario III: As in scenario II but with } \\
\text { additional intervention in first two grades }\end{array}$ & 4.50 & 4.03 & 3.20 & 2.70 & 2.30 \\
\hline $\begin{array}{l}\text { Other interventions: } \\
\text { Reduce class size ( } 50 \% \text { ) (assume increased } \\
\text { performance, future attainment by } 5 \% \text { ) }\end{array}$ & 1.10 & 1.20 & 1.30 & 1.50 & 1.70 \\
\hline $\begin{array}{l}\text { Reduce class size }(50 \%) \text { with building cost } \\
\text { (assume increased performance, future } \\
\text { attainment by } 5 \% \text { ) }\end{array}$ & 0.90 & 1.00 & 1.10 & 1.20 & 1.30 \\
\hline $\begin{array}{l}\text { Raise teacher salary }(50 \%) \text { (assume } \\
\text { increased efficiency, student achievement, } \\
\text { college entry by } 5 \%)\end{array}$ & 1.70 & 1.50 & 1.20 & 1.20 & 1.20 \\
\hline $\begin{array}{l}\text { Incentives to students }(\$ 200 / \text { year/child), } \\
\text { assume increased enrollment in } 1 \text { st grade by } \\
5 \%\end{array}$ & 2.00 & 1.80 & 1.00 & 0.50 & 0.30 \\
\hline $\begin{array}{l}\text { Computers (assume improved learning, } \\
\text { increased employability, productivity by } \\
5 \% \text { ) }\end{array}$ & 1.00 & 1.10 & 1.20 & 1.30 & 1.30 \\
\hline
\end{tabular}

\section{Conclusion}

This paper summarized the socioeconomic conditions of children around the world. It used the framework of the Copenhagen Consensus, as part of a larger effort to take stock of the world's biggest problems and the most promising solutions. It presented an in-depth assessment of the costs and benefits of solutions to some of the problems facing children today. We placed emphasis on results from rigorous studies, impact evaluations and randomized experiments. Although the cost-evidence literature is scarce, a good case for early interventions and key quality-enhancing education interventions exists. 


\section{References}

Angrist, J. and V. Lavy. 2002. "The Effect of High Schooling: Some Lessons for the Economics of Education." Journal of Economic Literature 40: 1167-1201

Angrist, J.D. and J. Guryan. 2005. "Does Teacher Testing Raise Teacher Quality? Evidence from State Certification Requirements." IZA Discussion Papers 1500.

Armecin, G., J.R. Behrman, P. Duazo, S. Ghuman, S. Gultiano, E.M. King and N. Lee. 2006. "Early childhood development through an integrated program: evidence from the Philippines." World Bank Policy Research Working Paper Series 3922.

Attanasio, O., E. Battistin, E. Fitzsimons, A. Mesnard and M. Vera-Hernandez. 2006a. "How Effective are Conditional Cash Transfers? Evidence from Colombia." Institute for Fiscal Studies Briefing Note No. 54.

Banerjee A., S. Jacob, M. Kremer, J. Lanjouw and P. Lanjouw. 2005 "Moving to Universal Primary Education!" Processed

Banerjee, A., S. Cole, E. Duflo and L. Linden. 2004. "Remedying Education: Evidence from two randomized experiments in India." MIT. Processed

Barnett, W.S and L.N. Masse. 2006. "Comparative Benefit-Cost Analysis of the Abecedarian Program and Its Policy Implications.” Economics of Education Review (forthcoming).

Barnett, W.S. 2004. "Does Head Start have lasting cognitive effects? The myth of fade-out." In E. Zigler and S. Styfco, eds., The Head Start Debates. Baltimore, MD: Paul H. Brookes Publishing Co.

Barnett, W.S. 1995. "Long-term effects of early childhood programs on cognitive and school outcomes." The Future of Children 5: 25-50.

Basu, K. 1999. "Child Labor: Cause, Consequence and Cure, with Remarks on International Labor Standards." Journal of Economic Literature 37.

Belli, P.C. and O. Appaix. 2003. "The economic benefits of investing in child health." Washington, DC, World Bank, Health, Nutrition and Population Discussion Paper.

Berlinski, S., S. Galiani and P. Gertler. 2006. 'The Effect of Pre-Primary Education on Primary School Performance." University College London. Processed

Carneiro, P. and J. Heckman. 2003. "Human Capital Policy," in J. Heckman and A. Krueger, eds., Inequality in America: What Role for Human Capital Policy. Cambridge: MIT Press. 
Case, A. and A. Deaton. 1999. "School Inputs and Educational Outcomes in South Africa." Quarterly Journal of Economics 114(3): 1047-1084.

Cigno, A., F.C. Rosati and L. Guarcello. 2002. "Does Globalization Increase Child Labor?" World Development 30(9): 1579-1589.

Coady, D.P. and S.W. Parker. 2002. "A cost-effectiveness analysis of demand- and supply-side education interventions." FCND discussion papers No. 127, International Food Policy Research Institute.

Currie, J. and D. Thomas. 1995. “Does Head Start Make a Difference?" American Economic Review 85(3): 341-364.

Duflo, E. 2001. "Schooling and Labor Market Consequences of School Construction in Indonesia: Evidence from an Unusual Policy Experiment." American Economic Review 91(4): 795-813.

Feijo, M. 1984. "Early Childhood Education Programs and Children's Subsequent Learning: A Brazilian Case." Unpublished Ph.D. Dissertation, Stanford University.

Filp, J., C. Cardemil, E. Donoso, E. Schiefelbein, J. Torres. 1983. "Relationship between PreSchool and Grade One Education in Public Schools in Chile," in IDRC, Preventing School Failure. Ottawa: IDRC.

Gertler, P., H. Patrinos and M. Rubio-Codina. 2006. "Empowering parents to improve education: evidence from rural Mexico." World Bank Policy Research Working Paper Series 3935 .

Glewwe P. and P. Olinto. 2004. "Evaluating of the Impact of Conditional Cash Transfers on Schooling: An Experimental Analysis of Honduras' PRAF Program.” USAID.

Glewwe, P., H.G. Jacoby and E.M. King. 2001. "Early childhood nutrition and academic achievement: a longitudinal analysis." Journal of Public Economics 81: 345-368.

Glewwe, P., M. Kremer, S. Moulin and E. Zitzewitz. 2004. "Retrospective vs. Prospective Analyses of School Inputs: The Case of Flip Charts in Kenya." Journal of Development Economics 74(1): 251-68.

Glewwe, P., N. Ilias and M. Kremer. 2003. “Teacher Incentives.” National Bureau of Economic Research.

Glewwe, P. 1997. "A Test of the Normality Assumption in the Ordered Probit Model." Econometric Reviews 16(1): 1-19. 
Glewwe P., M. Kremer, S. Moulin and E. Zitzewitz. 2000. "Retrospective vs. Prospective Analyses of School Inputs: The Case of Flip Charts in Kenya." NBER Working Papers 8018, National Bureau of Economic Research, Inc.

Glewwe, P. 1999. The economics of school quality investments in developing countries: an empirical study of Ghana. New York: St. Martin's Press.

Hageman F., Y. Diallo, A. Etienne and F. Mehran. 2006. Global Child Labour Trends. International Labour Office, SIMPOC.

Hall, G. and H.A. Patrinos (eds.). 2006. Indigenous Peoples, Poverty and Human Development in Latin America. Palgrave Macmillan.

Hanushek, E. 1995. "Interpreting Recent Research on Schooling in Developing Countries." World Bank Research Observer 10: 247-254.

Heckman, J.J. 2006. "Skill Formation and the Economics of Investing in Disadvantaged Children." Science 312: 1900-1902.

Heckman, J.J. 2004. "Lessons from the Technology of Skill Formation." Annals of the New York Academy of Sciences 1038: 179-200.

Heckman, J.J. and D.V. Masterov. 2004. "The Productivity Argument for Investing in Young Children."

International Programme on the Elimination of Child Labour (IPEC). 2004. Investing in Every Child, an Economic Study of the Costs and Benefits of Eliminating Child Labour. Geneva: International Labour Office.

Jacob, B. and L. Lefgren. 2004. "Remedial Education and Student Achievement: A RegressionDiscontinuity Analysis." Review of Economics and Statistics 86(1): 226-244.

Kagitcibasi, C., D. Sunar and S. Bekman. 1987. "Comprehensive Preschool Education Project: Final Report.” Istanbul, Bogazici University.

Kremer M., E. Miguel and R. Thornton. 2004. "Incentives to Learn." The Brookings Institution.

Kremer M., S. Moulin and R. Namunyu. 2002. "The Political Economy of School Finance in Kenya." World Bank.

Maluccio, J.A. and R. Flores. 2004. "Impact Evaluation of A Conditional Cash Transfer Program: The Nicaraguan Red de Protección Social." IFPRI FCND Discussion Paper No. 184. 
Miguel, E. and M. Kremer. 2004. "Worms: Identifying Impacts on Education and Health in the Presence of Treatment Externalities." Econometrica 72(1): 159-217.

Pianto, D.M. and S. Soares. 2004. "Use of Survey Design for the Evaluation of Social Programs: The PNAD and PETI." Processed

Pontieri, M.J., M.L. Ferrari Cavalcanti, and Y.R. Gandra. 1981. "Avaliação do Aproveitamento Escolar de Pre-Escolares do Programa Centro de Educação e Alimentação do Preescolar." Revista de Saude Publica 15: 148-158.

Psacharopoulos, G. 1997. "Child labor versus educational attainment Some evidence from Latin America." Journal of Population Economics 10(4): 377-386.

Psacharopoulos, G. and H.A. Patrinos. 1997. "Family size, schooling and child labor in Peru: An empirical analysis." Journal of Population Economics 10(4): 387-405.

Psacharopoulos, G. and H.A. Patrinos. 2004. "Returns to investment in education: a further update." Education Economics 12(2): 111-134.

Rahim, A. and P. Holland. 2006. "Facilitating Transitions for Children and Youth: Lessons from Four Post-Conflict Fund Projects." Social Development Papers No. 34, World Bank.

Raju, D. 2005. "The effects of conditional cash transfer programs on child work: A critical review and analysis of the evidence." World Bank, Washington, DC.

Ravallion, M. and Q. Wodon. 2000. "Does Child Labour Displace Schooling? Evidence on Behavioural Responses to an Enrollment Subsidy." Economic Journal 110(462): 158175.

Rosati, F.C. and M. Rossi. 2003. "Children's Working Hours and School Enrollment: Evidence from Pakistan and Nicaragua." World Bank Economic Review 17(2): 283-295.

Schultz, T.P. 2004. "School Subsidies for the Poor: Evaluating the Mexican PROGRESA Poverty Program.” Journal of Development Economics 74(1): 199-250.

Sommers, M. 2002. "Children, Education and War: Reaching Education For All (EFA) Objectives in Countries Affected by Conflict." Working Papers Conflict Prevention and Reconstruction Unit Paper No. 1, Education Team, Human Development Network, World Bank.

Temple, J.A. and A.J. Reynolds. 2006. "Benefits and Costs of Investments in Preschool Education: Evidence from the Child-Parent Centers and Related Programs. Economics of Education Review (forthcoming). 
Unesco. 2005. Children out of school: Measuring Exclusion From Primary Education. Montreal: UNESCO Institute of Statistics.

UNICEF. 2005. The State of the World's Children 2006. New York: UNICEF.

UNICEF. 2002. Addressing the Affordability Gap: Framing Child Care as Economic Development. Finance Development: Invest in Children. New York.

UNICEF. 2000. Poverty Reduction Begins with Children. New York.

van der Gaag, J. and J.-P. Tan. 1998. "The Benefits of Early Child Development Programs: An Economic Analysis." World Bank.

World Bank. 2005. Reshaping the Future: Education and Postconflict Reconstruction. Washington, DC.

World Bank. 2002. Arab Republic of Egypt: Strategic Options for Early Childhood Education (Report No. 24772-EGT). Washington, DC.

World Bank. 2001. Brazil: Early Child Development: A Focus on the Impact of Preschools (Report No. 22841-BR). Washington, DC. 